\title{
FRIESLAND'S BELASTINGEN IN DE VORIGE EEUW.
}

I.

„Wanneer men den rijkdom, grootte en blocienden toestand van de onderscheiden provinciën der Vereenigde Nederlanden met clkanderen vergelijkt, on toffens ovorweegt hoo veel van de meeste zaaken in Friesland meer aan den lande betaald moet worden, dan in de overige Gewesten, zoo hecft men reden om zich te vel'wonderen, dat deze Provincie, geduurende zo lang ecne reeks van jaaren, dus gedrukt heeft kumnen worden, zonder geheel verloren te gaan."

Met deze woorden vangt de Schrijver van don "tegenwoordigen staat van Friesland" het hoofdstuk over Frieslands geldmiddelen aan. 1) En clders schrijft hij: „Wannecr men zijn oog vestigt op de grootheid dezer lasten, in vergelijking van lezelve in verscheiden naburige provinciën, moet men besluiten, dat in F'riesland 's Lands gelden worden verkwist, of dat deeze provincie verre boven haal vermogen, in evenredigheid van andere provinciën, in de Quotas, die an de Generaliteitskasse moeten worden betaald, is bezwaard. Wat het eerste aangaat kan men het tegendecl zeer gemakkelijk bewijzen; naardien de publicke zaaken voorzeker in geene provincie zuiniger en met meer overleg worden behandeld dan in Friesland; terwijl er ook geene provincie is, in welke men, in evenredigheid haarer uitgebreidheid en vermogen, minder Amptenaaren heeft; waarbij nog komt, dat de aanzienlijko Amptenaaren in Friesland zo weinig uit 's Lands kassen genieten als ergens. Waarom dan de steeds bekrompen staat van F'rieslands geldsmiddelen, niettegenstaande de enormiteit der belastingen, alleen in het tweede artikel, dat is in de veel te hooge anschrijving in de Quota ter Gencraliteit moet worden sezocht." 2)

Het was niet voor de eerste maal, dat op dit anubeeld werd

1) Salmun. T'egcenwourdigo Staat ran Friesland. Heflst. III. blz. 337.

2) id. blz. 490 . 
greslagen. Vooral Zeeland en Friesland achtten zich in dat opzicht bovenmation bozwaard. Reeds bij de laatste vaststelling der quotae, in het jaar 1616, had laatstgenvemd gewest tegen zijn quota geprotesteerd en geëischt, dat deze zou worden terug grebracht op $f 9-8-9,1)$. Desniettegenstaande werd het bepaald op. $f 11-13 \rightarrow 4$. In den loop der $17 \mathrm{e}$ eeuw deden de Staten van Friesland achtereenvolgens in de jaren $1631,1635,1674$ en 1675 pogingen om hierin verandering te krijgen, welke pogingen echter allen mislukten.

Toen de langdurige Spaansche successie-oorlog 's lands finantiën uitputte traden Friesland's Staten krachtiger op en drongen in 1709,1710 en 1711 herhaaldelijk aan op het sluiten van een "raisonnabele vrede; declarecrende bij herhaalde secreete Resolutiën aan de Gecommitteerden ter Generaliteit tocgezonden, en aldaar in een besoigne geopend, dat zij buiten staat waren om iets verders ter voortzettinge des Oorlogs te contribueeren; hebbende die geene, welke ter dier tijd het meeste bewind der zaaken in handen hadden, aan dezelve Staaten ernstig gerepresenteerd, de gevolgen, die daaruit voor de Republiek en hare geallieerden zouden proflueeren, en ermstig voorgehouden dat haar Ed. Mog. deze declaratiën geliefden te verbergen, dezelve vleijende met de gelukkige successen van den oorlog, en de avantagieuse gevolgen daaruit te spruiten, tot verligtinge der Provintiën uit de geconquesteerde Steeden on Landen, en uit een te formeeren Barriere, bij zoo verre deeze Repnbliek zig bij haare Geallieerden constant hield, en aan Friesland doende hoopen, bij eene verkreegene Vreede, haare finantien te zullen te gemoete komen; en daarop is het draagende gehouden tot den ongelukkigen uitslag na de Bataille van Denain, en aan de veranderingen in het systhema van Engeland, waar door de Staat genoodzaakt wierd tot het besluiten van een Vreede, zeer verre geëloigneerd van die, welke men zich had vooringebeeld, na zoo veele ongemeen gelukkige Oorlogssuccessen." ?

Toen men met meer halstarrigheid dan wijsheid den oorlog wenschte voort te zetten had men Friesland met hoop op herstel zijuer grieven gevleid, toen het vrede was geraakten de gedane toezeggingen in het vergeetboek.

1) N. Tpey. Verhandeling over de quotae. Harl. 1784. blz. 31.

2) Deductie der redenen, up welke de proviucie vin Friesland fundeert haar verzuek en pratetengio ow in hare quutio in de Generaliteitslasten verligt te worden. 
Hierop volgde in 1718 de meesterlijke deductie van Jhr. Ph. Vegelin van Claerbergen, Grietman van Haskerland. Hierin laat de schrijver Holland buiten rekening, daar hij verklaart omtrent het inkomen van deze provincie niets te durven bepalen. De inkomsten der zes overige geweston geeft hij voor het jaar 1716, aldus op:

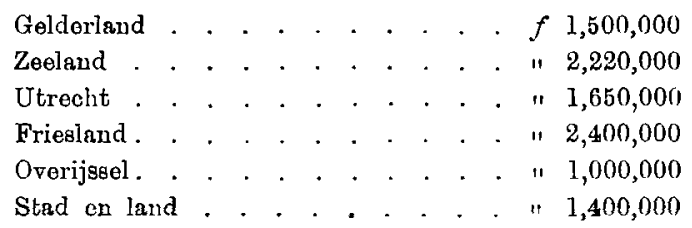

De quotae voor de zelfde provintiën beliepen voor:

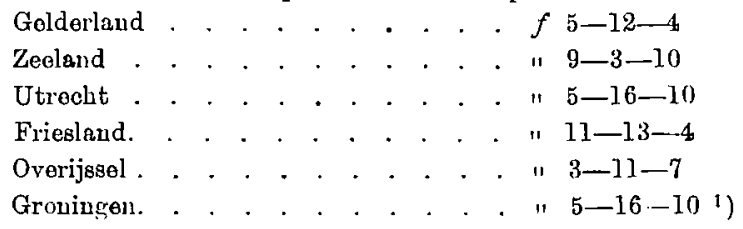

Hieruit blijkt, dat Friesland, in vergelijking met Gelderland b.v. eene quota betaalde als ware zijn inkomen niet $f 2,400,000$ maar $\int 3,120,000$.

De opgaven van den hoogleeraar Ypey komen met die van Jhr. Vegelin tamelijk wel overeen. Alleen Utrechts inkomsten stelt bij iets lager en wel op $f 1,525,000$, terwijl hij daarentegen die van Stad en lande op $f 1,525,000$ brengt. Hollands inkomsten raamt hij op $f\left(14,835,000 .{ }^{2}\right.$ )

Volgens deze maatstaf berekent de Franeker hoogleeraar, dat de quotae der verschillende provinciën naar billijkheid aldus behoorden te worden bepaald:

$$
\begin{aligned}
& \text { voor Gelderlaud op } f \text { 5-19-14 d. i. } f \text { 0-7-10 honger } \\
& \text { "Holland " "59-8-14 " " 1-2-11 hooger } \\
& \text { "Zeeland " " 8-15-13" " } 0-7-13 \text { lagel. } \\
& \text { "Utrecht " " } 6-1-14 \text { " " } 0-5-4 \text { hooger } \\
& \text { "Frieslaud " " 9-11-13 " " 2-1-7 lager } \\
& \text { "Overijssel " "3-19-14 " " } 0-8-7 \text { hooger } \\
& \text { "Stad on lande " "6- 1-14 " " } 0-5-4 \text { hooger 3) }
\end{aligned}
$$

Dan ofschoon de grietman van Haskerland zelf ter Generaliteit werd afgevaardigd om "nadere instantiën bij Hunne Hoogmogenden te doen", de zaak bleef bij het oude. De Staten van Friesland

1) Teg. Staat. III. 491.

2) N. Ypey. Verh. blz. 21.

3) Ypeij. Verh. Job. VI. 
gingen voort met humne pogingen om opheffing hunner billijke grieven te verkrijgen. De krachtigste poging was die van 1770 toen zij hume reeds door ons anngehaalde deductie ter algemeene Statenvergadering inzonden.

Dit hoogst belangrijke staatstuk, waarvan de kopie berust in de Provinciale Bibliotheek van Friesland, welke kopie mij door den Heer Bibliothecaris welwillend ter inzage werd afgestaan, zag het licht, naar aanleiding van het voorstel om nten voordeele van de Provintie van Zeeland, wegens haar bezwaarden toestand, geduurende eenige achtereenvolgende jaaren, het volle beloop der 300,000 Glds tot de Fortificatiën buiten de stemmende Provintiën welke aan alle de zeven geunieerde Provintiën en 't Landschap Drenthe, elk pro quota, op den Staat van Oorlog staan gerepartiticert, van 't toekomende provisioneel alleen ter repartitie van Zeeland over te brengen."

Ofschoon dit met de ${ }_{n}$ allergevoeligste on smertelijkste aandoedoening" geschiedde, meenden toch de EdelMogenden van Friesland tegen deze bevoorrechting van Zeeland, dat toch al het leeuwenaandeel uit dat geld trok, op te moeten komen en geen toestemming te kumnen geven, ndan voor zooveel het aan de Provintie van Friesland onschadelijk zoude zijn en dat het aan derzelver uitgeputte finantien geen nadeel toebragt." Zij achtten het "volstrekt noodzakelijk dat Haar Hoog Mog. en alle Leden der Unie, door de gegrondheid der argumenten, meermalen en tegenwoordig wederom op nieuws ter toetse der waarheid bijgebragt, op het nalrukkelijkst mogen geconvinceerd worden, dat deeze Provintie veeleer in haar eigen aandeel redres of verligting noodig had en behoorde te obtineeren, dan dat dezelve uit haare defectueuse gesteldheid nog an de Provintie van Zeeland zoude te gemoet moeten komen."

${ }_{n} \mathrm{Om}$ al het welke zoo klaar doenlijk voor te stellen en demonstratief aan te dringen, zullen haare Ed. Mog.

Eerstelijk, Vertoonen de gelegenheid en toestand van Friesland, ten einde de overige Provintiön daar naa humne eigen gesteld. heid mogen vergelijken, en daaruit moeten besluiten hoe zeer de meenigvuldige en zwaare disasters, welke deeze Provintie beneevens, jaa booven haare meedegenooten, en derzelver finantiën, ten uitersten verzwakt hebben.

Ten Tweeden, dat om te voldoen aan het binnenlands vereisch ter herstellinge van de geleedene schaade, en zo veel moogelijk voor te koomen nieuwe rampen, en om teffens, met inspanninge van alle vereischte kragten, als getrouwe Bondgenooten zig te 
kwijten, in die pligten, welke haar Ed. Mog. aan de Unie verschuldigd zịnn, niets hebben naagelaaten, om die te vinden uit zoodanige overzwaare lasten, dat ze, altoos ophoopende, nooit verminderende, aan de Ingezeetenen ondragelijk geworden zijn.

Ten Derden, Dat deeze Provintie reeds geïtereerde aanzoeken heeft gedaan tot redres of soulaas.

Ten vierden, Dat deeze bekommerlijke toestand en boovenmaatige bezwaardheid niet alleen billijkt de bepaalde declaratie ten opzigte van Zeeland gedaan, maar dat ook volgens de gronden van gezonden redenen, natuurlijke aequiteit en volstrekte noodzaakelijkheid, de overige medeleeden der Republiek verschuldigd zijn, om van gelijken deeze Provintie als een verswakt bondgenoot te hulpe te koomen en te soulageeren, en dat daar toe reeds zoo veelvuldige representatiön zijn gedaan; doch dat dezelve niet hebbende gehad het gewenschte affect tot eenige de geringste vertroostinge of reëel soulaas, haar Ed. Mog. zich hebben genooddrongen gevonden, om hunne regtmatige klagten als nog te vernieuwen, in billijke hoope van eindelijk verhoord to worden.

Ten vijfden, Dat dezelve op het nadrukkolijkste haar Hoog Mog. moeten onder het oog brengen, de deplorable gevolgen, welke, door aanhoudende weigering, daaruit noodzaakelijk moeten proflueeren bij de geringste ligt gebeurlijke extraordinaire toestanden." 1)

Op de gronden en bewijzen voor dit alles aangevoerd, komen we later terug. Thans zij slechts vermeld, dat ook deze wanhoopskreet zonder gevolg bleef. Ten einde raad dreigde Friesland, dat het zijn quotae eigenmachtig zou weten te verminderen en bracht in 1783 die bedreiging werkelijk ten uitvoer door terughouding op de betaling der quotae. Toen werd in 1784 eene commissie benoemd, die met een algemeen onderzoek naar het finanticwezen belast werd. Het volgende jaar werd aan eene tweede commissie de taak opgedragen eene herziening der quotae voor te bereiden. Het duurde tot 1790 eer deze commissie aan de Hoog Mogenden rapport uitbracht. Zij verklaarde zich in beginsel tegen het behoud der quotae, doch met het oog op de mocielijkheden, waarop zij gestuit was, betwijfelde zij de mogelijkheid van het invoeren van een stelsel van algemeene belastingen. ${ }^{2}$ )

\footnotetext{
1) Deductie. bldz. 1 en 2.

2) Het verdient opmerking, hoe reeds in 1543 het denkbeeld eener inkomstenbelasting werd uitgesproken. In dat jaar toch bracht eene der steden, ter vergadering van Holland, eone belasting naar het geschatte rermugen ter sprake. De Raad vau Holland verklaarde, dat zulk eene belasting "ran
} 
Aldus komende tot handhaving der repartitie bij quotae, bepaalde de commissie zich tot het voorstellen van verbeteringen in dat stelsel. Hierbij hield ze zich aan den nieuwen Stat van Oorlog, door den Raal van State opgemaakt volgens de gegevens der Commissie van 1784. Hierop werd eindelijk in 1792 eene herziening door de Hoog Mogenden tot stand gebracht. Ze bepaalde zich tot eene wijziging der quotae. $\mathrm{Bij}$ deze regeling, die voor den tijd van 25 jaren werd vastgesteld, werd vooral aan de bezwaren van Zeeland en Friesland tegemoet gekomen. Friesland's quota werd van ruim $11 \frac{1}{2}$ Ct. op $9 \frac{1}{2}$ pCt., die van Zeeland van ruim 9 pCt. op $3 \frac{4}{5}$ teruggebracht. Daarentegen werd de quota van Holland tot $62 \frac{1}{20} \mathrm{pCt}$. verhoogd. 1 .

II.

Alvorens over te gaan tot het beantwoorden van de vraag in hoeverre de wanhoopskreten van Friesland's Statea gegrond waren, willen we cen beknopt overzicht geven van de inrichting van het finanticel beheer der provincie. Zooals mon weet, liep lit in de verschillende gewesten zeer uiteen. Zonderlinger dan in Friesland was het nergens. Te dezen opzichte bestond er eene bepaalde neiging tot decentralisatie. Zoo werd het Kantoor-Generaal, aan welks hoofd een Ontvanger-Generaal stond, eerst tijlelijk en in

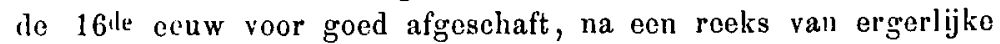
processen ter zake van verduistering van gelden door dat Kantoor. ")

De inrichting van het finantieel behecr was ongeveer als die van con huisvader, dic zijn inkomsten in verschillende zakjes bewart, naar gelang van de bron, waaruit ze voortvlocien en den inhoud dier zakjes ook weer voor verschillende rubrieken van uitgaven besteedt. Men had namelijk vier kantoren, t. w. dat vau de domeinen en consumtiën, dat van de floreen, lat van de losse renten en dat van de lijfrenten. Elk kantoor had zijn eigen rubriek van ontvangsten en uitgaven.

Boven deze kantoren stond de Provinciale Rekenkamer, waartoe elk der vier kwartieren Oostorgo, Westergo, Zevenwouden en de Steden één lid committeerden. Deze leden hadden zitting voor

alle het rodelijkst scheen, doch tevens, dat ze bezwarlijk goed te regelen zou ziju on daarenboven aanleiding zou geven thit vele valsche eeden, daa. niemand zijne goederen te recht zou annbrengen. Wagenar. Vaderl. hist. V. 250 .

1) Tegenwrordige Stant van Stad on Lande. XX. bldz. 8 en 9 .

2) F. N. Sickengr. Bijdrage tıt do geschiedenis der belastingen in Nederland. bldz. 286.

LCON. 1890 . 
den tijd van drie jaren. Bovendien was aan de Kamer toegrevoegd een secretaris, een pensionnaris en een kumınies of klerk. Zij kwam steeds gelijktijdig met de Gedeputeerde Staten samen. De oprichting dagteekent van het jaar 1584, haar laatste instructic van 1680. Zij was belast met het toczicht op de Provinciale Geldmiddelen, het onderzoeken van de rekeningen der ontvangers, het liquideeren der declaratiën en de zorg, dat er geen ordonnaniën werden verleend, in strijal met de resolutiën der Staten. "Bij de grebecle inrichting van het finantieel beheer", aldus sehrijft de Heer Sickenga in zijn boven angehaald proefschrift, „werd gemist een goed geregelle verantwoordelijkheid, die reeds van zelve uit eene openbare behandeling van alle zaken, dat beheer betreffende, had moeten voortvloeien." Telkens worden er dan ook klachten genit, dat er in tal van takken van administratic een volslagen duisternis heerscht. Wat Friesland in het bijzonder aangaat, blijkt de geheel onvoldoende toestand van dat beheer zonneklaar uit het beruchto proces tegen den Ontvanger-Generial in 1637. 1) Dan ook elders was het niet beter gesteld. Zoo kwam men in Holland, bij het uitbruken van den oorlog in 1672, bij een onderzoek nar den staat van het Kantoor-Generaal, tot de min aangename ontdekking, dat de provinciale kas gehecl ledig was, terwijl or toch op 31 December 1670 nog een bedrag van $f 9,000,000$ anwezig had moeten ziju. ") Aan het stelsel van geheimbouding weet dan ook le Raadpensionaris van de Spiegel het gezonken crediet der provincic Holland. Daarom stelde hij voor het invoeren van een jaarlijkschen Staat en Balans van de inkomsten en uitgaven ${ }^{\text {als }}$ het eenige en ware middel om het algemeene vertrouwen te wimnen." 3 )

$\mathrm{Na}$ deze korte uitweiding gaan we over tot het beantwoorden van de vraag, of inderdaad Frieslands ingezetenen zoo zwaar gedrukt werden als de Heeren Ed. Mogenden het in hume deductie doen voorkomen.

"De lasten deezer Provintie," aldus heet het in dit staatstuk, „hebben haar source:

1. Uit het geen van de Vastigheden proflueert.

2. Uit de Waren, die geconsumeerd en verbruikt worden.

3. Uit gemengde en allerlei zoortige oorzaaken.

4. En eindelijk uit de Domainen.

1) Zie rver dit proces: Wagrenaar. Vad. hist. XI. bdlz 22: o. v. Slingelandt. Staitk. geschr. III. bdlz. 135 e. $\nabla$.

?) F. N. Sickenga. Bijdr. bldz. 2!j.

3) P. L. v. d. Spiegel. Brieven en negutiatiëm. III, blz. tU e. ₹. 
De sub 1 vermelde bron vloeide uit den natuurlijken staat van zaken het mildst. Immers "het is overbekend", zoo heet het t. a. p., ndat de Provintie van Friesland genoegzaam alleen bestaat uit de Culture en voortbrengselen der Landerijen, zijjnde de Graanen, het Vee en het Suivel; en maar weinig deel heeft aan de groote Navigatie, gelijk Holland en Zeeland."

"Het provenu der Landen komt voort uit de middelen:

1. Van de Floreen Renthe.

2. Van de Reëele goedschattinge.

3. Van de Schoorsteengelden.

4. Van de bezaaide Landen.

5. Van het Kueijen- en Paardengeld.

6. Van de Verkoopingen van onroerende Goederen, t'elker alienatie." 1)

De eerstgenoemde belasting was de oudste en tevens de meest opbrengende en dagteekende uit den tijd der Saksische overheersehing (1492-1515). Vooral Hertog George deed krachtige pogingen om 's lands inkomsten, die onder zijn' vader en broeder noy gcheel onbepaald waren, op een vasten voet te breugen. Zijn eerste poging daartoe dagteekent van het jaar 1504. Do hertog had de leensopdracht van alle vaste bezittingen der Friesche edelen geëischt. Toen waren Easge Heringa van Hoxwier, Heerschap te Mantgum, Edo van Jongama, Heerschap te Rauwerd, Doecke van Martena, Heerschap te Kornjum, Rienck van Kamstra, Heerschap te Jelsum, met nog zes andere edelen, door de te Leeuwarden vergaderde Hovelingen afgevaardigd om Hertog George, die toen te Harlingen vertoefde, van dien eisch af te brengen. ${ }^{2}$ ) De heeren slaagden in hunne zending, echter alleen op voorwaarde, dat zij zich verbonden jaarlịks de een-en-twintigste penning humer landrente op te brengen. Of de sluwe Saks hiermede zijn eigenlijk doel niet bereikto en of het hem met de handhaving zijner leenheerlijke hoogheidsrechten ooit ernst is geweest, mag op zijn minst betwijteld worden. Echter werd deze belasting slechts een tiental jaren opgebracht. In 1514 toch, toen George in oorlog was met Graaf Edzard van Oost-Friesland, stelde hij den Heerschappen voor de 21 ste penning af te koopen of af te dienen. $\mathrm{Zij}$ verkozen het laatste en men $\mathrm{kwam}$ overeen, dat zij gedurende drie maanden 500 krijgsknechten ten dienste des vorsten zouden onderhouden en daarvan voor zich en hunne erven

1) Doductie. bla. 2 en 3.

2) Friesche Vulksalmanak yur het jaar 1890. bldz, 53. 
vrij zouden zijn van de $2 \mathrm{I}$ ste penning. Te vergeefs trachtte keizer Karel $V$ later op die vrijstelling terug te komen. Nog in 1545 werden alle gepriviligieerde Heerschappen of humne erven op last van Z. M. door den Procureur-Generaal voor het Hof van Friesland gedaagd, echter zonder het door den keizer gewenschto gevolg. 1)

Van meer blijvenden aard was de flore en-belas ting, insgelijks door Hertog George in 1511 iugevoerd. Hij liet een nauwkeurig onderzoek instellen hoeveel iedere plaats of stuk los land aan florenen of goudguldens van 28 stuivers kon opbrengen en bepaalde, dat daarvan jaarlijks $2,3,4$ of 5 st. betaald zou worden. „En is geformeerd", aldus de deductie, „uit een zeer nauwkeurige teekeninge der toenmalige huuren, betaald wordende in eene Munte, bekend onder den naam van Florijnen, nu Goudguldens genaamd, van welke te dier tijd, een, twee a drie stuivers wierden geheven ten behoeve van de loopende gemenne kosteu, en welke nu gesteigerd tot 126 stuivers, dat is twee Ducatons, en daarbij onveranderlijk zijn gebleeven zeederd meer dan 70 jaaren herwaards." 2)

Niet licht zal men de drukkende last van deze grondbelasting overschatten. Het was een steeds dieper invreetende kanker, die aan het welzijn van de ingezetenen knaagde. Bịj hare instelling bracht ze $13,951 \mathrm{fl}$. op; in de laatste helft der 18 de eeuw was ze tot $f 768,227$ gestegen. ${ }^{3}$ )

Drukkender nog werd deze belasting door do ongelijkmatigheid, die langzamerhand in dezen ontstond. Wel is waar werd de floreenrente over de geheele provincie volgens vasto kohieren geïnd, maar toch ontstonden weldra belangrijke wijzigingen, vooral door het bij placcaten toegestaan verleggen van florenen van het eene stuk land op het andere en door het wegspoelen of bederven van landerijen door overstroomingen als anderszins. Wat het eerste aangaat werd het aldra gebruik geheele plaatsen of gedeelten er van vrij van floreen te verhuren of te verkoopen, waardoor de last, die oorspronkelijk op een geheele plaats lag, op een deel daarvan of wel ten name van den voormaligen eigenaar kwam. Dat laatste had ook plaats, waar landerijen door het

1) Register vau aaubreng van 1511 en verdere stukken de floreenbelasting betrekkelijk, uitgegeven dorr het Friesch genrotschap van geschied-, rudheid. en taalkunde. I. blz. VI.

2) Deductie. bldz. 6 .

3) Tegenw. Strat. IV. bldz. 338. 
water verzwolgen werden. Daaruit laat zich het verschijnsel ver. klaren, dat sommige landerijen zoo bovenmatig bezwaard werden, lat de eigenaars geld toegaven om er van af te komen.

Dat bij een dorgelijken toestand ontduikingen en pogingen daartoe veelvuldig voorkwamen, behoeft bijna nauwelijks gezegd. Herhaaldelijk werden dan ook placcaten uitgevaardigd om het toczicht te verscherpen en de ontduiking tegen te gaan, placcaten, waarin het aan bedreiging met $z$ ware straffen tegen de nalatigen niet ontbrak. We noemen de resolutie van 21 Juli 1688 en de placcaten van 5 Maart 1722, 10 Sept. 1729 en 31 Mei 1759.

Opmerking verdienen vooral de strenge bepalingen, voorkomende in het placcaat van 1729. "En in geval", zoo lezen we aldaar, "eenige florenen mochten gebracht zijn ten laste van personen, zonder dat eenige landerijen, waarop voorsz. florenen zouden leggen, aangewezen zijn, of door de Gerechten aangewezen worden, waardoor het Landt wordt gefrusteerd van zijn onderpant, en bij verval van zodanige Personen, dewelke persoonlijk, zonder uitdrukkinge van vastigheden, in de voorschreven cohieren bekend staan, gehouden zullen wezen, om voor St. Jacobi 1730 aan de Gerechten, op welker register de zelve aangeslagen staan, oplossing en aanwijzinge te doen van de landen, of huijzen, waarop de florcen, op haare personen staande, heeft gelegen, of in gevalle zodanige aanwijzinge niet zal konnen geschieden, dat zij als dan verplicht zullen wezen, haare andere landerijen of vastigheden, die suffisant zijn tot hoedinge der lasten, met voorsz. personeele floreenen te beswaren; doch wanneer zij geen vastigheden in eigendom hebben, of die zij bezitten de lasten niet kunnen hoeden, dat zij in zulken gevallen gehouden zullen wezen, om voor yeder floreen, waarmede zij persoonlijk op het cohier bekent staan, in 's Lands Comptoir van den ontfanger Knock over te brengen een somma van een hondert rijksdaalders, des dat daarvoor obligatien worden gegeven met interessen tegen vier ten hondert, welke interessen $z \mathrm{ij}$ zo lange zullen trekken, als zij hare florenen aan den Lande betaalen, het zelve doceerende met quitantiën, zonder vertooninge van welke quitantien zij geen interessen zullen vermogen te ontfangen, verblijvende ondertusschen de opgeschotene penningen ten allen tijde, tot vergoedinge van verloorene florenen, in 's Landts Comptoir, zonder dat de geëxtradeerde obligatiën, oijt of oijt afgelost zullen mogen worden; alles bij poene van vijfentwintig goudene friesche rijders, te converteeren naar 's Lands Ordonnantie, en te verbeuren bij alle de gene, 
die van dezen na te komen in gebreeke zullen blịven. 1)

In hetzelfde placcaat werd bepaald, dat wamneer eene plaats werd gescheurd of gedeeld, nalle percelen landts, onder zodanige gescheurde plaatse behoort hebbende, mitsgaders alle de successive eijgenaars derzelver, met elkander responsabel zullen zijn voor do gehcele floreen, waarmeede zodanig cen gescheurde plaats staat. aangeslagen."

Men ziet het, de Edel Mog. waren er op bedacht er voor to waken, dat niemand door de mazen van het net ontsnapte en zelfs van die landerijen, die door het water verzwolgen waren, de floreenbelasting werd betaald.

Wat aangaat het totaal dezer belasting blijkt uit het Cohier van 1785, dat zij opbracht:

$$
\begin{aligned}
& \text { in Onstergo. . . . . . f } f 59,992-21 \\
& \text { in Westergo. . . . . . " } 472,890-18-2 \\
& \text { iv Zevenwouden . . . . " } 86,765-15-9 \frac{1}{2} \\
& \text { in de Steden . . . . . " 48,230- } 1-131 \\
& \text { Totaal . . . . } \overline{f 767,778-27-9}
\end{aligned}
$$

Het hoogst stouden aangeslagen Wijmbritseradecl met 9,335 flor. tot een totaal bedrag van $f 58,812-16-4$ en Leeuwarderadeel met 8,256 flor., opbrengende $f$ 52,012-16; het laagst Harlingen, waar 37 flor. f $236-5$ opbrachten en Sloten met 124 flor., vertegenwoordigende een waarde van $f 783$.

In de meeste grietenijen was het totaal bedrag nog iets hooger dan op het landscohier was opgegeven. Dat hooger bedrag, op de dorpslijsten voorkomende, noemde men „overschietende floreenen." Zij kwamen ten bate van de ontvangers dier belasting.

\section{III.}

Naast deze landflorenen stonden nog de dijkflorenen. Het is echter eene vaak voorkomende dwaling, waarin zelfs de schrijiver van de Tegenwoordige Staat van Friesland schijnt te vervallen, ${ }^{2}$ ) deze beide belastingen met elkaar in verband te brengen. Ze hadden, zooals door Mr. W. W. Buma duidelijls is angetoond, niets gemeen dan den naam. ${ }^{1}$ )

Oorspronkelijk werden Frieslands zeedijken door de gezamenlijke ingezetenen met hand-en spandiensten aangelegd en onderhouden. Later werd an zeker grondbezit het onderhoud van een

1) Tegenw. Staat. IV. 364 u. v.

2) Tegenw. Staat. IV. bldz. 339.

s) Reg. van aaubreng van 1511. XVII, 
hepaald gedeolte toegrewezen. Dit was b. v. in Oostilongeradeel sudert 1503 het geval. ${ }^{3}$ ) Dan wa len Kerstmisvloed van 1717 zagen de Staten van Friesland het onvoldoende van cene dergelijke regeling in. Vandaar de resolutie van 1 Maart 1.718, volgens welke "het onderhoud zoo vall paal- als van aardwerk gemeen gemaakt zou worden."

$\mathrm{Bij}$ een nadere resolutie van 28 April 1718 werd de regeling dier zaak aan het Hof van Friesland opgedragen. Eene Commissie, bestaande uit drie landmeters, werd nu belast met de taak om te taxeeren op hoeveel floreenen het onderhoud van elke roerle zeedijk moest worden gesteld. Deze taxatie wisselde af van $\frac{k}{\xi}$ tot $19 \frac{1}{2}$ floreen. Inşevolge de resolutie van 1 October 1718 - men ziet, dat de Staten er geen gras over lieten groeien - werd nu een nicuw dijkboek aangelegd en werd de verschuldigde opbrengst. wegens het onderhoud der dijken voor elk der dijkgenooten vastgesteld. Het totaal bedrag van deze geheel op zich zelf staande belasting beliep gemiddeld $f 140,000 .-$ per jaar.

Een niet minder drukkende belasting dan de floreenrente was de reëele goedschatting, dagteekenende uit den tijd van den Spaanschen successic-oorlorr. Het was alweder eene belasting op de huurwaarde en dus ten slotte niet veel anders dan eene nieuwe florcenbelasting onder een anderen vorm, ze werd echter niet alleen van landerijen, doch ook van huizen, molens, enz. geheven. "De reëelo goodschatting", aldus schrijven de Edel Mogenden in hume declaratie van 1770 , nis een nieuw geïntroduceerd middel, wel meermalen geproponeerd, dog om de enormiteit van zulk een ondraagelijken last nooit ter conclusie gebragt als toen, wanneer de trouwhartigheid dezer Provintie, om de gemeene zaak in den Oorlog over de Spaansche Successie, niet alleen na, maar ook booven vermoogen te handhaven, al die obstakels te boven kwam, en dezelve voor de eerste maal in den Jare 1711, niet zonder merkelijke oppositie in train deed brengen; dog als te zeer bezwarende en daarom tegen den inborst van veele Regenteı en Ingezetenen strịdig, wederom nagelaten wierd in den Jaare 1712.

Maar het gebrek van andere en betere middelen om zig te redden, on de vleijende hoope, dat het van korten duur zoude zijn, deed die Last andermaal hervatten in den jaare 1713.

En heeft om dringende reedenen moeten grecontinueerd worden. Van Anno 1713 tot 1741, met tusschenpoozingen van eenige

1) Charterbook II. 226 en 241 . 
meerdere of mindere verligtinge in de proportie van dien Last, dog zecderd dien tijd tot nu toc, zonder cenigre intermissie of verandering, altoos op de zwaarste tarief blijvende

Deze Last vordert een 4de part der zuivere huuren, die er booven de Floreenrenthe en kosten der reparatiën op de vastigheden overschieten, en is danrom bepaald ten opzigte der vasto goederen, die geen onderhoud van Timmeragio onderheevig zijn, op één Gulden van vier, die het in huur rendeert, en van éen gelijke Gulden van zestehalve noopens goederen, die zoodanige reparatiën vcreischen, en welke geraamd worden met dic propositie evenredig te zijn, hoewel het gewone onderhoud, vernieuwing en toevallige ongelukken, alsmeede de last der Watermoolens, die er in de laage landen noodzakelijk en veelc zijn, op den duur de boovengemelde propositic zcekerlijk te booven gaan en lastiger zijn dan de $\frac{1}{4}$ der vrije goederen.

l'e ongemeene drukking van deezen Last valt van zelve in het oog, en kan als een tweede Floreen Renthe aangemerkt worden, verminderende niet alleen do rovenues maar ook den prijs der Eigendommen met een vicrde gedeelte." 1)

Inderdaad eischte deze belasting niet minder dan $25 \mathrm{pCt}$. der huurwaarde, na aftrek der floreenrente. Zelfs wordt er in de deductie op gewezen, dat men in den Jaare 1744 het zoo boovengewoon en lastig middel der reëele goedschatting, dubbel heeft doen heffen, zonder dezelve wederom in de 50ste Punning in Compensatie te mogen brengen, gelijk bij eenige Provintiën, noopens extraordinaris Nood-opschotten, is toegelaaton en gepractiseerd geworden." 2)

Hier echter maken de Edel Mogenden zich aan een kleine overdrijving schuldig. Wel is het een feit, dat de eigenaars van vastigheden in het genoemde jaar $50 \mathrm{pCt}$. van het inkomeu, dat ze daaruit trokken, in de reëele goedschatting hebben opgebracht, doch daaronder waren $25 \mathrm{pCt}$. begrepen voor welke men obligatiën ontving, rentende $3 \mathrm{pCt}$, die later ten laste der steden en grietenijen werden gebracht.

Telt men de tot dusver genoemde belastingen bij elkander, dan mag men gerust aannemen, dat onze voorouders van voor honderd jaren minstens $50 \mathrm{pCt}$. der oplorengst hunner vastigheden moesten opbrengen.

Tot "hetgeen uit de vastigheden proflueert," brachten de staten

1) Deductie, bldz. 6 .

?) id. bldz. 11 . 
verder: de opbrengrst van schoorsteengeldon, van de bezaaide landen, van het Koeijen- en Prardengeld en van de verkooping. van unrocrende Goederen. De vier eerstgenoemden vormden met de belasting op de hoofden de zoogenaamde „vịf speciën."

Het schoorsteen- of haardstedegelden beliep $f$ 3.- por schoorsteen; voor de stookhutten bij boerenwoningen en voor vecstallen slechts 15 st. Pastoriën werden op 2 , onderwijzerswoningen op 1 schoorsteen borekend. Hoe de Staten er op uit waren te zorgen, dat steeds de belasting ten volle binnen kwam, blijkt uit eene bepaling, dat voor huurhuizen, verhuurder en huurder ieder de helft in deze belasting te betalen hadden, ${ }_{n}$ doch indien de Huurder zijne helft niet op zijnen tijd kan betaalen, is echter daarom de Eigenaar niet van 't betaalen zijner helft bevrijd. Integendeel, indien de huurder ten laatste volkomen insolvent wordt bevonden, is de Eigenaar, in dat geval, verpligt de betaaling van 't geheelo schoorsteengeld te voldoen." ").

Ten opzichte van de belasting op de bezaaide landen en op runderen en paarden werd onderscheid gemaakt tusschen de meer vruchtbare lanclon van het hoog kwartier en cle minder vruchtbare van het laar kwartier. Welke tot het eerste en wolke tot het tweede gerekend werden was nauwkeurig bepaald. Volgens de Ordonnantic op de bozaaide landen, werd van elke pondemate bouwland in het hoog kwartier 10 st. 12 p. betaald, in het laag kwartior iets minder. Van het hoornve betaaldo men, van ieder rund boven de drie jaar $f^{\prime} 1-15-4$ in het hoog-, $f 0-21-8$ in het laag kwartier. Stieren en inlandsche ossen waren vrijgesteld. Aan paardenpacht werd opgebracht 14 st. per paard. Veulens waren tot Mei van deze belasting vrijgesteld.

Het recht, geheven bij den verkoop van onroerende grooderen was reeds van oudere datum. Oorspronkelijk bedroeg dit de 56ste penning bij elke overuracht, doch bij de nijpende geldnood werd dit in 1723 op de 40ate penning bepaald. ${ }^{2}$ ).

De tweedo rubriek van inkomsten, in de deductie genoemd, vlocide voort uit „de waren, die geconsumeerd en verbruikt worden."

Om tot een oordeel te komen omtrent het bedrag dezer belastingen, die ingevorderd werden $n$ op de Havenen en Passagies te lande, bij het inkomen in de Provintie, en daarom Haven-impositiën grenoemd worden," zullen we alwoder de deductie laten spreken. Deze dan deelt mede, dat de belasting geheven werd van: ${ }_{n}$ de

1) Tegeuw. Stant. XVI. bldz. 395 .

2) Deductie. bldz. 7 . 
Jakenen en Kraamerijen, Havor- Speciön of gewone Waaren, Zocte Waaren, Wịnen en vreemde Bieren, zoo die bij den Burger ingeslaagen, als die ten Tappe geslecten worden, Koftij en Thee, enz. Tabak, Uitheemsche Brandewijnen en sterke Wateren en Zout.

Van een groot gedeelte derzelven wordt hetaald, de 5re Penning van de waardij met cen tiende verhooging daarboven.

De Wijnen geeven dertig Guldens per Oxhootd.

De Brandewijn een Gulden de Kan.

De Koffij vier en le Thee agt stuivers per Pond.

De Tabak drie stuivers.

Het Zout, ieder zak van 40 Frieschu maten, twee Guldens tien Stuivers, it tweo Guldens vier Stuivers.

De overige zoolanige Middelen, die bimmenlandsche genoemd worden, zijn :

De belasting op het Gemaal, en daaronder begrepen die van de himenlandsche Brandewijnen of hecte Wateren en de gebrouwen Bieren.

Do Impost op ieder Zak of Loopen, uitmakenre een 35ste part vall cen Last, beloopt noopens

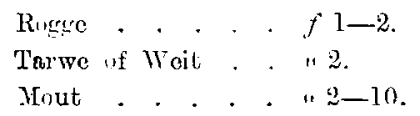

Gemengide Soorten naar cvenredigheid.

De Gortmakkers zijn resteld voor cen loopersteen op 800 Guldens roor jeder Paard, en dubbeld met twee Parrden.

De Pelmolonars na proportie van de Vlugt der Molenrocien, on cnkele of dubbele steenen, zijn meele gebragt op ecn taux van 400 tot 825 Guldens ieder.

De stookers van gredistilleerde Wateren betalen van ierler Stook-keetel, een Aam uroot zijude, 330 Gls en weegens minderc on mecrlere grootte na proportie; boven en behalven het Zakgeld roornoemd tot 2 Gls 4 st. van ieder loopen zak.

Nog behoort tot de binnenlandsche consumptieve Producton, de Impust op Turf en Brandhout tot cen zestehalv van de wardij van cen Daaliter.

En le Impost op het Beestiaal bedraagt 4 st. 6 peun. van ioder Goulgulden." 1

Om conigszints te kunnen oorleelen over de oplrengst dezer belastingen, ontleencn we een paar posten ain le opgave der "Middelen op 't Comptoir der Losse Renthen."

1) Deductie blz. 7 . 
Gemaal, zooals Meị 1769 verscheenen, afgereliend is, en waturondor hegreepen is het zakgeld der inlandsehe hecto en godistilleerde wateren. . . . . . . . . f 412,439-3-6

Beestiaal. Als boven. . $f$ 136,519-17-8

Dog overmits de zware

Versterfte nu mincler

gerekend. . . . $, 50,000$

Turf $86,519-17-8$

Turf en brandhout. Als boven . . . . , $75,736-1-6$

Brandewijuen . . . . . . . . . . " $53,784-15-6$

Waagregt. . . . . . . . . . . " 25,819-6-12

Passagiegeld . . . . . . . . , 13,500-4 cnz.

Een deel dezer belastingen, die, zooals men ziet, niets anders waren dan inkomende rechten, werden godurende cen korten tijd opgcheven, ten gevolge van het oproer van 1748. Omtrent de oorzaken van dat oproer loopen de lezingen uiteen. De hooglecraar Ypey geeft als zoodanig op, dat er door burgemeesters van Harlingen fraudes zouden zijn gepleegd door het verkoopen van ambten. In weerwil van hunne bekentenis, onttrokken de Staten hen aan de vervolging van het Hof van Friesland. De hicrdoor vorwekte verbittering zou de naste aanleiding tot de genocmdo troubelen zijn.

Aamemelijker komt ons de volgende lezing voor: Boeren van Buitenpost hadden landerijen in bezit of in pacht onder Gerkesklooster. Om hun vee te melken en andere werkzamheden to verrichten, moesten zij dagelijks cen paar malen de grenzen der provincie passeren en telkens werd van hen het passagegeld tot cen bedrag van 3 st. geëischt. Hiertegen verzetten zij zich en toen de Procureur-Generaal uit Leeuwarden vorscheen om dwangmaatregelen in toepassing te brengen, namen zij hem gevangen en lieten hem nict los, dan nadat hij beloofd had geen revanche over het voorgcnomene te zullen nemen.

Weder afwijkend zijn de in den Tegenwoordige Staat van Friesland voorkomende mededeelingen. Volgens deze was de beweging van den beginne af gericht tegen de pachters der inkomende rechten en der specieën. Vooral tegen de havenpachters was men reeds lang in geschrifte opgekomen. Ook was het gerucht algemeen vorbreid, dat de Stadhouder, die inderdaad zich meermalen er over uitgelaten had, dat alle pachten behoorden afgeschaft en door andere belastingen vervangen te worden, in zijne goede bedoelingen door de Staten werd tegengewerkt. De groote hoop meende dus op het gezag van den Prins te kunnen steunen, toen 
zij in verzet $\mathrm{kwam}$. Het oproer brak het eerst ten platten lande uit in de maand Mei. Van daar sloeg het naar de steden over. De pachtershuisjes werden onder den voet gehaald, de ketenen, waaraan do gortmolens 's nachts werden vastgelegd, om te voorkomen, dat er ter sluiks gemalen zou worden, met geweld verbroken, terwijl de oproerlingen den korenmolenaars en bakkers. aanzegden, dat zij geene pachtecduls meer te halen badden.

In deze omstandigheden besloten de Edel Mogenden, daartoo anigezocht door de gecommittecrden uit de breede gemeente, de pachten af te schaffen, wat bij proclamatie aan het volk werd bekend gemaakt. In plaats daarvan werd nu eene quotisatie ingevoerd. De gemiddelde opbrengst der afgeschafte belastingen werd geraamd als volgt:

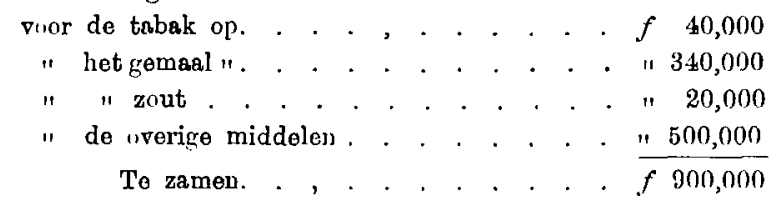

Die f 900.000 nu werden over de dertig grietenijen en elf steden van Friesland omgeslagen, naar den maatstaf van het aantal inwoners en het totaal inkomen, volgens den opbrengst van de 100sto en 1000ste penning, een taak, die aan den geleerden Ypey werd opgedragen. Op de zelfle wijze werd het bij te dragen bedrag voor elk gezin bepaald. 1)

Dat deze belasting, vooral met het oog op de ontwikkeling van den handel, belangrijke voordeelen, in vergelijking met de afgeschafte pachten aanbood, is buiten kijf. Dan slechts korten tijd bleef ze in stand. Niet alleen vond ze verzet bij velen, die door de afschaffing der verpachtingen, groote voordeelen ontbeerden, doch ook verhieven zich van alle kanten klachten over een to hoogen aanslag. Eerlang keerde men terug tot de afgeschafte bo. lastingen, doch niet tot de verpachting. In plaats daarvan werden kommiezen aangesteld, wien de inning der belastingen werd opgedragen. Waarschijnlijk heeft ook in dit opzicht de vroegtijdige dood van Willem IV een nadeeligen invloed uitgeoefend.

Alvorens van deze rubriek van belastingen af te stappen, nog een enkel woord. Men wane niet, dat de Ed. Mog. in hunne deductie alle artikelen opnoemden, waarvan belasting werd betaald. Bijna geen enkel artikel van dagelijksch gebruik was onbelast. Om enkele voorbeelden te geven, werden o. a. rechten geheren:

1) Tegenw. Stant. XIV. blz, 114 e. v. 


$$
\begin{aligned}
& \text { Vau een gros tabakspijpen . . . . . } 6 \text { st. } 8 \text { p. } \\
& \text { Van ieder spel speelkaarten. . . . . } 8 \text { p. } \\
& \text { Van een riem schrijfpapier . . . . . } 10 \text { st. } \\
& \text { Van ieder pond koperdraad. . . . . } 11 \mathrm{p} \text {. }
\end{aligned}
$$

Men staat inderdaad verbaasd over de minutieuse zorgvuldigheid, waarmede de autoriteiten er voor waakten, dat zelfs de meest onbeduidende zaken niet aan de mazen van het door hen gespannen net ontsnapten.

\section{IV.}

Als derde bron van inkomsten noemen de Staten in hunne deductie de opbrengst voortvloeiende uit gemengde en allerlei soortige oorzaken. Deze bestonden uit:

het regt van collaterale successie,

het passagiegeld,

het Waagregt,

het Klein Zegel,

het Jaarlijks en vast Amptgeld,

het Hoofdgeld,

de ongeliquideerde persooneele Goedbelasting.

Als collateraal successierecht werd $2 \frac{1}{2}$ pCt. van het netto bedrag van erfenissen en legaten betaald.

Het passagegeld was eene buitengemeen drukkende belas. ting, zooals we reeds zeiden, zou dit volgens sommigen de anlleidende oorzaak zịin geweest tot het oproer van 1748 .

Het bedroeg:

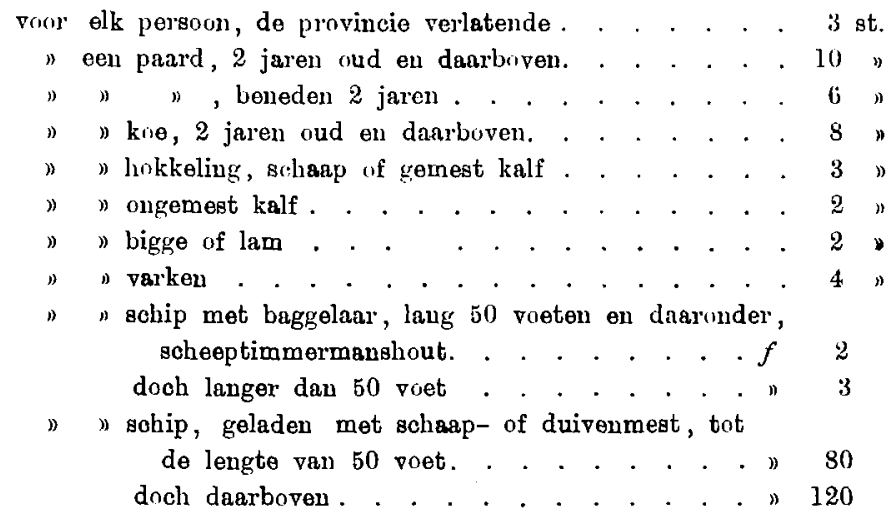

Van deze belasting waren enkele vrịstellingen toegekend en wel, behalve aan Z. D. H. den Heer Prinse Erfstadhouder en alles wat tot Hoogdeszelfs Huis behoort, „aan de ordinaire Schippers en 
Voerlieden, die reizende persoonen buiten de Provincie brengen, vour paarden tot de rijtuigen van voerlieden behoorende, aangemeene Soldaten en Matrozen, van arme lieden, en na het oproer van 1748, ook voor vee, dat uit of bimnen de Provincie ter weide graat."

Het Waagrecht werd betaald van alles, wat grewoonlijk bij het gewicht wordt verkocht en varieerde van 3 tot $1 \frac{1}{2}$ st. per 100 pond.

Van veel belang was het Jaal lijks-en vast Amptgeld. Deze cxorbitante belasting, later bekend oncler den naam van Acquivalent, werd op nieuw reregeld bij het placeant van 6 Mei 1776 .

Wij 19do ecuwsche ambtenaren, die reeds een klaaglied aanheffen, wamnecr van ons inkomen, gedurende eenigen tijd een deel gekort wordt als storting in het pensionfonds, wat moeten wij dan wel zoggen van onze voorgangers in de vorige eeuw, dic inderdaad beduidende sommen te storten hadden in 's lands schatikist, hij de aanvaarding humner betrekking: Wo zullen unze lezers niet rermocien met de opgave van de greheele lijst, doch scehts enkele grepen doen. De storting bedroeg voor:

\begin{tabular}{|c|c|c|c|c|c|}
\hline en & Luitenant-Admimal & . & & & . $f 9000$ \\
\hline$"$ & Schout-bij-Nacht . & . & . & & . 1) 3000 \\
\hline " & Secretaris vau do Admiraliteit & 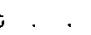 & & & . . 14500 \\
\hline$"$ & Secretaris van het Landschap & & & & $" 4500$ \\
\hline " & raadsheer. & & & & $" 3000$ \\
\hline$n$ & "ntianger der Hrreon-rente & & . & & $" 4500$ \\
\hline$n$ & Kamerbude der Staten. . & . & & & $" 1000$ \\
\hline$"$ & Kamerbride van Gedeputecrde & Staten & & & 11000 \\
\hline$n$ & grietman & - & & & $" 6000$ \\
\hline " & muntmeester & . & . & & $\Rightarrow 1000$ \\
\hline$"$ & stempelsuijder . & . & & & . " 1000 \\
\hline 1) & postmoester. & . & & & 5000 \\
\hline (7) & lakkonmeester & & & & 1000 \\
\hline
\end{tabular}

"Alle verdere Ampten en Bedieningen", aldus genoemd placeaat, ${ }_{n}$ in bovenstaande lijst niet hegrepen, moeten een jaar tractement ten profịte van den Lande laaten staan." ').

En behalve die sommen, die bij het aanvaarden van eene betrekking werden gestort, moesten bovendien de zoogenaamde officicgelden jaarlijks worden betaald. Deze varieerden van / 12 voor de minst bezoldigde tot $f 72$ voor de meest bezoldigde ambtenaren ${ }^{2}$ ).

Het recht van $\mathrm{Klein} \mathrm{Z}$ egel werd geheven van alle papicren, 't belang vim bizondere personen rakende. Alle acten en contracten

1) Placenat ras 6 May 1776.

2) Tecenw. Stant IV bldz. 449 e. $r$ 
moesten voorzicn zijn van cen zerel. De hocgrootheid daarvan hing af van de in de acte genocmule som. Berloeg dezo som

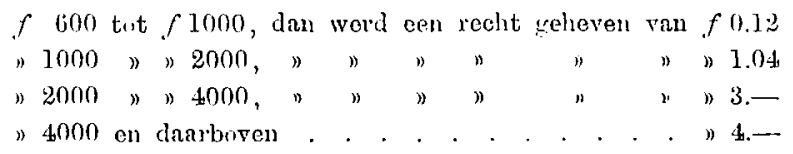

Voor testamenten, disponeorende over goederen, ter waarde vall minder dan $f 10,000$. . werd oon zegel van $f 3$ vereischt; voor die van $f$ 10,000. - tot $f 20,000$. - cen zegel van $f$ 6.- ; voor die van $f 20,000$. - tot $f 40,000$. - cen van $f$ 12.-; vonr die van $f 40,000$. - en daarboven, een van $f$ 24.- . Zoo was het berlrag van het zegelrecht ook voor alle transactiën andere bepantt.

Het hoofdgeld, dat hehalve in Friesland, ook in het kwartier van Zutphen, in Overijssel en Star en Lande werd geheven, ontwikkelde zich langzamerhand uit het dienstborengeld. Laatstgenoemde belasting werd het errst in Holland ingevoerd in 1636; vijf jaren later in Zeeland en langzamerhand volgrlen de meeste provinciën dit voorbeeld. In Holland werd het twee malen in 1680 en 1749 - verhoogd en in latstgennemd jaar uitgestrekt. tot gouverneurs en gouvernantes, huis-en kantoorklerken, winkelbedienden en tuinlieden. 1). In Friesland ging men verder en strekte de belasting over allo hoofden uit. Het heliep of 3.- voor olk persoon boven den twaalfjarigen leeftijd, wanneer het hoofd les huisgezins aan geld, obligatiën, vastigheden, koopmanschappen, cnz. de waarde van zeshonderd guldens of daarboven bezit; wordende hieronder ook gerekend Predikanten, schoolmcesters. hooge en lagere officieren, die hier in Garnizoen liggen, en vast. traktement trekken, mids staande op Friesche Repartitie, grelijk ook de Dienstbooden van alle zodanige personen. Daarentegen kunnen diegeenen, wolke geen zeshonderd gulden bezitten, man, vrouw of dienstboden, hoofd voor hoofd, volstaan met jaarlijks, te betaalen dertig stuivers." 2)

De personeele goedschatting werd betaald tot een bedrag: van elf per mille, volgens een aanslag over het geheele vermogen, waarbij korting werd toegestaan voor alles, waarvoor reeds op andere wijze belasting werd betaald, de obligatiën op andere provinciën, voor zoover aldaar een soortgelijk middel werd geheven en de obligatiën op vreemde staten. Verder genoten vermogens beneden

1) Recuei] van Ordonnantiën der Gemeene middelen. No 23 , bldz. 1. Art. 1,2 en 3 .

3) Tegeuw. Staat IV. bldz. 396 . 
de $f 500$. - vrịstelling van deze belasting. Sedert 1774 betaalde echter de aldus vrijgestelden een weekgeld van 1 of 2 stuivers.

Tie in 1742 vastgestelde kohieren dezer belasting bleven onveranderd tot 1776. Toen werd tot een herziening overgegaan. Door afsehrijvingen bij vertrek uit de provincie en andere oorzaken, werd de opbrengst steeds geringer. Bij den val der Republiek was ze tot $f$ 4,000. - gedaald. 1 )

Ten opzichte van de vierde bron van inkomsten der provincie zegt de deductie: „De vierde soort van Middelen bestaat uit Goederen en Revenuën, eertijds geschikt voor de Hecren des Lands en daarom Dominalia genaamd, en bestonden in Landen loor de Zee aangespoeld en ingedijkt, zijnde voornaamelijk die welke althans onder de Grietenije van den Bild behooren, en eenige weinige andere; voorts uit geringe impositiën op Wịnen, Bieren en Likeuren gelegd, die men Excijsen noemde, en het overige uit eenige Curalia. Uit deeze inkomsten en eene bijgevoegde modique somma door 't Landschap te fourneeren, hadden die Heeren zig verplicht de bescherming der Landen op zich te neemen, om de Justitie te doen administreeren: ten eerste tijden van Keizer Karel den V, was dat bijvoegsel gereguleerd op 1000 Goudguldens, onder expresse conditie van die met geen meordere praecariën en impositiën to beswaaren; maar naderhand werd op instantelijke beeden of petitiën door propinen vermeerlerd, als 1550 met $50,000 \mathrm{Gls}$; 1554 met 40,000, dog kort daar na met 60,000 geaurgmenteerd; 1560 door koning Philippus I weder op 60,000, en eindelijk 1572 tot 128,000 Gls gehragt; de Landerijen verkocht en de Excijsen onder andere Impositiön, die daarmerle vermecrderd zịn, nauwelijks iets meer dan de naam over." 2)

Nog mosten we met een enkel woord melding maken van de zoogenaamde declskosten. Hieronder verstond men het inkomen van den Grietman, dat gevonden werd uit een omslag over de florenen en uit de zoogenaamde consentgelden ${ }^{3}$ ). Het berliag van dat inkomen is, zooals de Heer van Slooten in de laatste Friesche Volksalmanak heelt uiteengezet, vaak zeer overdreven voorgesteld. Immers tal van uityaven $k$ wamen te zijne laste. Zoo bedroeg, om een voorbeeld te noemen, het tractement van den Grietman van Aengwirden, volgens het met de ingezetenen

i) F. N. Sickenga, Bijdr, tot de gesel, der bel. in Nel. bldz. 452.

2) Deductie bldz. 8.

s) Lauds ordomnantie. 1e Briek. Tit. XI. Art. 10 e. v. 
dier gemeente gesloten contract van 19 Maart 1780, $f$ 1300.-.

Zijne uitgaven echter waren de volgende:

Daggelden voor de volmachten ten Landsdage, Adelijke Staat $f 162$

id. eigengeörfde Strat. . . . , . . . . . . . . " 82

Secretaris . . . . . . . . . . . . . . . . . " 25

Executcur . . . . . . . . . . . . . , " 25

Assistenten ter Distributie vau den Grietman. . . . . . . ก 45

Gevangenhuis of bewnarder van 't blok. . . . . . . . . " 25

Rechtkamerhuur . . . . . . . . . . . . . . 25

Crimiseele Justitie . . . . . . . . . . . . . . . . " 20

Oitvaugers-tractement . . . . . . . . . . . . „100

Totaal . . . . . . . . . . . . . . $f 5 n 9$

Zoodat ten slotte het zuivere tractement van den Grietman zich bepaalde tot $\int 791 .-{ }^{1}$ )

Naar het schịnt sprongen de Grietmannen dikwijls willekeurig met dien omslag om. Reeds in 1673 werden voorstellen gedaan om deze zaak op een meer vasten voet te brengen, terwijl in de $P_{0}$ incten der Gecommitteerden van het Quartier Sevenwouden van den 5den Junij 1748 de eisch wordt gesteld, ${ }_{n}$ dat de Grietman alle jaaren eene nette Reekening zal moeten doen van de tijd af, dat hij Grietman geweest is, voor twee Gevolmagtigden uijt ijder Dorp." 2).

In datzelfde jaar werd de zaak nu werkelijk geregeld bij het Reglement Reformatoir van den 21sten December. Hierbij werd eene overeenkomst gesloten tusschen den Grietman en de stemgerechtigde ingezetenen, in zake het tractement. Bij den omslag over de floreenen moest in aanmerking genomen worden de grootte der grietenijen en de uitgaven, die uit de deelskosten betaald moesten worden, terwijl bij het vaststellen van het bedrag der floreenbelasting tevens rekening moest worden gehouden met de opbrengst der consenten. ${ }^{3}$ ).

Het ligt niet in onze bedoeling dieper in te gaan op de vraag in hoeverre Frieslands Staten recht hadden in hunne bewering, dat ze bij de quotisatie bovenmatig zwaar waren belast. Dat dit trouwens inderdaad wel het geval was, blijkt reeds uit het feit, dat de bevolking van Friesland - in 1670 op omstr. 140,000 zielen geschat - tot die van Hollands stond als $1: 7$; terwijl de quotae zich verhielden als $1: 6$; terwijl zeker de maatschappelijke welstand van Hollands bewoners bij die der Friezen niet achter-

1) P. J. D. v. Slooten. De Deelekosten. Bijdragen, betreffeude het inkomen of de bezoldiging der Grietmannen. Friesche Volksalmanak. 1890.

2) Verwardt Frieslandt, No 6.

s) P. J. D. v. Slooten. De Deelskosten.

Econ. 1890. 
stond. Dat deze inderdaad niet groot geweest is blijkt uit het feit, dat het Collateraal Successierecht in de zijlinie, dat tot een bedrag van $2 \frac{1}{2}$ pCt. geheven werd, in 1768 slechts $f$ 13500. - opbracht.

Natuurlijk kan slechts bij benadering worden bepaald hoe zwaar de druk was, die door de gezamelijke belastingen op de bevolking werd uitgeoefend. Zooals we reeds opgemerkt hebben, mag men aannemen, dat van het inkomen, dat uit de vastigheden voortvloeide, minstens $50 \mathrm{pCt}$. aan belastingen moest worden opgebracht. De belasting, die men aan accijnsen betaalde, berekende de hoogleeraar Ypeij op 15 pCt. van hetgeen men verteerde. In de deductie lezen we nog te dier zake, bij eene vergelijking tusschen Friesland en de overige provinciën , dat in cenige derzelven (d. i. van de overige gewesten der Unie) geheele Huisgezinnen, die boven de gemeene Conditie uitmunten, in 't jaar kunnen volstaan, met de somme van $50 \mathrm{Gls}$. en daar beneden, voor alle de Imposten der gemeene Middelen, en de overige Huisgezinnen van minder qualificatie na proportie. Terwijl dezelve in Friesland oncindig meer beloopen, warover men te vooren zoo juiste begrootinge niet heeft kunnen opmaken, als wel naderhand is gebleeken, wanneer de heffinge daarvan voor een jaar was opgeschort, en daar en tegen bij eene vrij juiste taxatie, welke nogtans op den duur, door de gestaadige veranderinge, geen stand konde houden, de Familien en personen werden gequotiseerd.

Het welk voor een enkel persoon, vrijgezellende zonder huishouding leevende, bedroeg 7 Gls 17 st. en de geringste buishoudinge van twee armoedige persoonen op 11 Gis 13 st. en zoo. gradatim opklimmende, tot de aanzienlijkste op $300 \mathrm{Gls}$ en hooger gesteld." i)

Stelt men nu, met den Heer v. Slooten, ${ }^{2}$ ) het inkomen van zulk een armoedig gezin op hoogstens $f 60$, dan komt men tot de slotsom, dat zulk een arbeider ruim $12 \mathrm{pCt}$. van zijn inkomen aan belastingen had op te brengen. Grondbezitters en kapitalisten, en in 't algemeen meer gegoeden, moesten nog anders bloeden.

En toch waren nog telkens buitengewone maatregelen noodig om in 's lands behoeften te voorzien. Zoo werd, vooral op aandrang van Z. D. H. den Erfstadhouder, besloten tot het heffen van een Liberale Gifte, die geheven zou worden over de ge. heele Republiek en haar koloniën, tot een bedrag van 2 pCt. van

1) Deductie bldz. 10.

2) P. J. D van Slorteu. Nieuw-Advertentie-blad v. Heerenveen, $17 \mathrm{~N} \circ \mathrm{v}$. 1883. 
de opbrengst van het vermogen, volgens eigen aangifte der ingezetenen. ${ }^{1}$ )

In weerwil van dezen ondragelijken druk begrootten de Staten het jaarlijksch te kort op $f 305,626-11-10 .^{2}$ ) Geen wonder, dat ${ }$ Friesland geheel was uitgeput en binnenslands buiten alle crediet, en daarom genooddrongen op het geloof der Generaliteit te negocieeren $450,000 \mathrm{Gls}$. op Lijfrenthen van twee Lijven, tot een allerschadelijksten intrest van 8 pCt." ${ }^{3}$ )

Wij, negentiende-eeuwsche bewoners van Friesland, mogen klagen - en zeker niet zonder recht - over onze zware belastingen, toch moeten we erkennen, dat de lasten, die ons drukken, nog in de verste verte niet in vergelijking komen met die, welke ons voorgeslacht te dragen had!

J. C. van den Berg.

1) Nederlandsche Jaarboeken. 1747. II. bldz. 656. e. v.

2) Deductie. Bijl. A.

3) Deductie. bldz. 13. 